\title{
Changes in Depressive Symptoms among Older Adults with Multiple Chronic Conditions: Role of Positive and Negative Social Support
}

\author{
SangNam Ahn ${ }^{1,2, *}$, Seonghoon $\mathrm{Kim}^{3}$ and Hongmei Zhang ${ }^{4}$ \\ 1 Division of Health Systems Management and Policy, School of Public Health, The University of Memphis, \\ Memphis, TN 38152, USA \\ 2 Department of Health Promotion and Community Health Sciences, School of Public Health, \\ Texas A\&M University, College Station, TX 77843, USA \\ 3 School of Economics, Singapore Management University, Singapore 178903, Singapore; \\ seonghoonkim@smu.edu.sg \\ 4 Division of Epidemiology, Biostatistics, and Environmental Health, School of Public Health, \\ The University of Memphis, Memphis, TN 38152, USA; hzhang6@memphis.edu \\ * Correspondence: sahn@memphis.edu; Tel.: +1-901-678-5688
}

Academic Editors: Marcia G. Ory and Matthew Lee Smith

Received: 19 September 2016; Accepted: 19 December 2016; Published: 26 December 2016

\begin{abstract}
Depression severely affects older adults in the United States. As part of the social environment, significant social support was suggested to ameliorate depression among older adults. We investigate how varying forms of social support moderate depressive symptomatology among older adults with multiple chronic conditions (MCC). Data were analyzed using a sample of 11,400 adults, aged 65 years or older, from the 2006-2012 Health and Retirement Study. The current study investigated the moderating effects of positive or negative social support from spouse, children, other family, and friends on the association between MCC and depression. A linear mixed model with repeated measures was used to estimate the effect of MCC on depression and its interactions with positive and negative social support in explaining depression among older adults. Varying forms of social support played different moderating roles in depressive symptomatology among older adults with MCC. Positive spousal support significantly weakened the deleterious effect of MCC on depression. Conversely, all negative social support from spouse, children, other family, and friends significantly strengthened the deleterious effect of MCC on depression. Minimizing negative social support and maximizing positive spousal support can reduce depression caused by MCC and lead to successful aging among older adults.
\end{abstract}

Keywords: chronic illness; depression; social support; successful aging

\section{Introduction}

Depression significantly affects adults aged 65 years and older in the U.S. [1]. Up to $5 \%$ of older adults reported having major depression; the prevalence rises to $11.5 \%$ among older adults who are hospitalized and $13.5 \%$ when older adults require home healthcare [2]. In addition, lifetime experience of depressive disorder among older adults is projected to increase by $117 \%$ from 2005 to 2050 [3]. Notably, depressive symptoms can significantly increase morbidity and mortality [4], impair executive function [5], increase disability [6], and erode quality of life [7] among older adults. As the elderly population increases from 40.2 million in 2010 to 88.5 million in 2050 [8], the increasing pattern of late-life depression will escalate pressure on the U.S. healthcare delivery and financing system [1,9-12].

Recent studies have highlighted the association between multiple chronic conditions and late-life depression $[6,13,14]$. Although any chronic conditions can produce depressive symptoms, 
there are certain health conditions strongly associated with depression [6]. Inflammation can cause depression $[6,15,16]$ in the form of obesity $[17,18]$, osteoporosis $[19,20]$, asthma $[21,22]$, and osteoarthritis [23]. Impaired glucose metabolism can also be a risk factor for depression [6,24,25]. Prior studies demonstrated that diabetes elevated the risks of major depression by $15 \%$ and depressive symptoms by $20 \%$ [26]. Heart diseases can also cause depression due to poor adherence to treatment and lifestyle recommendations; dysfunction in the sympathetic, neuroendocrine, autonomic, immune, and inflammatory systems [27]. In addition, depression is frequently observed among patients with stroke [28], cancer [29], and hypertension [30,31].

Late-life depression, however, can be improved by cultivating the social environment including the groups to which the elderly belong and the neighborhoods in which they live [32]. Social support reflects one of many dimensions of social environment [33] and can affect mental health outcomes among older adults $[34,35]$. According to the stress-buffering model, positive social support can buffer the deleterious effects of stressful life events (e.g., bereavement, crime, layoff, social network crises) on depressive symptoms among older adults $[34,36]$. This buffer theory was still applicable when chronic diseases (e.g., arthritis) were positively associated with depressive symptoms, which were mitigated by various aspects of social support (including the presence of partner, having many close social relationships, feelings of mastery, a high self-esteem), especially when persons suffered from severe arthritis [37]. On the other hand, deficits in decent social support can be risk factors for depression in late life [6]. Negative social supports (or social restraints), including marital conflict, perceived family criticism, and depression in the spouse, can predispose older adults to developing or worsening depressive symptomatology and decrease life satisfaction $[6,38,39]$. Social restraints can be compounded when caregivers are burned out while providing care to their older family members especially those who suffer from multiple chronic conditions (MCC) [40]. Under the circumstances, it is hard to expect these informal caregivers to provide quality care to their care recipients [41].

Nevertheless, the literature is relatively sparse on how positive and negative social support can moderate the negative effects of MCC on depressive symptoms among older adults. Thus, the aims of this study were to (1) describe study participants' characteristics in terms of depression, number of chronic conditions, and positive/negative social support and (2) identify the moderating effects of positive/negative social support on the association between MCC and depression. The study findings can help policy makers further develop healthy social support systems to reduce depression among older adults with MCC.

\section{Material and Methods}

\subsection{Sample and Design}

The data for the present study come from the Health and Retirement Study (HRS), which is an ongoing, biannual, longitudinal panel study surveying a representative sample of 22,000 Americans over the age of 50 [42]. The present study is limited to participants who responded to the Leave-Behind Questionnaire pertaining to social support and are aged 65 or older. As such, the present study includes HRS interviews conducted in $2006(n=11,400), 2008(n=11,349), 2010(n=10,950)$, and $2012(n=10,747)$, spanning as many as 7 years. Respondents received a self-reported psychosocial questionnaire (including social support variables) every other wave (every 4 years) [43]. At baseline (year of 2006) of the present study, the study sample consisted of individuals age 65-85 years ( $M=74.9$, $\mathrm{SD}=7.6)$ where $57.3 \%$ were female and $68.4 \%$ had at least a high school diploma. Most study participants (83.5\%) were white while 13.3\% were African American. Further details of the HRS design, sampling procedures, data collection, and response rates were reported at a previous study [44]. The study sample size was 11,400 adults aged 65 years or older who reported perceived social support.

\subsection{Measures}

Health conditions of respondents were represented by the number of chronic conditions, commonly associated with depressive symptomatology, including hypertension, diabetes, cancer, 
chronic lung disease, heart condition, arthritis, stroke, and psychiatric/emotional problems [45]. These conditions were summed up to a score and recoded as 0-6 or higher based on distribution patterns.

The primary dependent variable in the study was depressive symptomatology, which was measured by an index summarized from eight symptoms of depression (felt depressed, everything was an effort, restless sleep, was (not) happy, felt lonely, (did not) enjoy life, felt sad, could not get going), ranging from 0 to 8 [46]. These items were based on the Center for Epidemiological Studies-Depression (CES-D) scale [47]. This scale was reported to have high internal consistency, reliability [48] and has been used for assessing the severity of depressive symptoms among older adults [46,49-51]. Respondents were asked how frequently they had experienced each symptom during the past week: 1 ("all or almost all"), 2 ("most of the time"), 3 ("some of the time"), and 4 ("none or almost none"). These responses were converted to Yes/No by setting "all" and "most" of the time equal to "Yes" and "some" and "none" of the time equal to "No". Created by summing the number of "Yes" answers across the eight items, a higher score (ranging from zero to eight) indicates greater depression symptomatology.

Positive and negative social supports were composed based upon a series of questions assessing quality of social ties and the quality of interaction with those social ties [52]. Of 4 relationship categories (i.e., spouse, children, other family, friends), there are 3 positively worded items (e.g., "how much do they really understand the way you feel about things?") and 4 negatively worded items (e.g., "how often do they make too many demands on you?") with 4 possible answers: 1 ("a lot"), 2 ("some"), 3 ("a little"), and 4 ("not at all"). After reversing these responses and averaging the scores within each dimension, a higher value indicates higher positive or negative social support. A previous report revealed psychometrics of alpha reliability across 4 relationship categories (positive social support from spouse $=0.81$; positive social support from children $=0.83$; positive social support from other family $=0.86$; positive social support from friends $=0.84$; negative social support from spouse $=0.78$; negative social support from children $=0.78$; negative social support from other family $=0.78$; negative social support from friends $=0.76$ ) [53].

Covariates included a set of demographic factors such as age, education (less than high school, GED, high school graduate, some college, college and above), sex, and race/ethnicity (white, black/African American, other).

\subsection{Data Analysis}

A linear mixed model with repeated measures for survey data using Stata 14.0 (StataCorp LP, College Station, TX, USA) was used to estimate the effect of MCC and its interactions with positive and negative social support factors in explaining depression among older adults (i.e., eight independent models). In these models, we controlled for age, gender, educational attainment, race/ethnicity, and survey wave.

In order to account for the panel nature of the data, we used the person-level weight provided by the HRS, which makes our sample a national representation of the non-institutionalized population in the U.S. aged 65 and older. Since the dependent variable and covariates were measured several times over different survey waves, we clustered standard errors at the person level to adjust for potential correlation of errors over time within the same person.

\section{Results}

Study participants' depression symptoms tended to improve between 2006 and 2010 but they slightly worsened in $2012(p<0.001)$ (Table 1). During this period, study participants reported having an increasing number of chronic conditions from 2.37 in 2006, 2.48 in 2008, 2.59 in 2010, and to 2.71 in 2012. However, we did not find statistically significant mean differences between the 2006 wave and the 2012 wave in terms of any positive or negative social support. 
Table 1. Description of variables of interest by wave.

\begin{tabular}{|c|c|c|c|c|c|}
\hline Variables & $\begin{array}{c}2006 \\
(n=11,400)\end{array}$ & $\begin{array}{c}2008 \\
(n=11,349)\end{array}$ & $\begin{array}{c}2010 \\
(n=10,950)\end{array}$ & $\begin{array}{c}2012 \\
(n=10,747)\end{array}$ & $p$-Value \\
\hline \multicolumn{6}{|c|}{ Mean (SD) } \\
\hline CESD depression (0-8) & $1.48(1.93)$ & $1.41(1.91)$ & $1.34(1.86)$ & $1.39(1.89)$ & $<0.001$ \\
\hline Number of chronic conditions (0-6) & $2.37(1.42)$ & $2.48(1.44)$ & $2.59(1.43)$ & $2.71(1.45)$ & $<0.001$ \\
\hline \multicolumn{6}{|l|}{ Positive social support } \\
\hline From spouse (1-4) & $2.94(1.01)$ & $2.95(1.02)$ & $3.02(0.99)$ & $2.97(1.00)$ & 0.2147 \\
\hline From children (1-4) & $2.70(1.04)$ & $2.71(1.05)$ & $2.68(1.04)$ & $2.69(1.04)$ & 0.7066 \\
\hline From other family (1-4) & $2.23(1.04)$ & $2.26(1.04)$ & $2.22(1.05)$ & $2.25(1.04)$ & 0.3899 \\
\hline From friends $(1-4)$ & $2.21(1.05)$ & $2.24(1.06)$ & $2.21(1.04)$ & $2.25(1.06)$ & 0.0784 \\
\hline \multicolumn{6}{|l|}{ Negative social support } \\
\hline From spouse (1-4) & $1.55(0.48)$ & $1.55(0.50)$ & $1.54(0.48)$ & $1.54(0.48)$ & 0.5833 \\
\hline From children (1-4) & $1.41(0.42)$ & $1.39(0.42)$ & $1.40(0.43)$ & $1.39(0.43)$ & 0.1192 \\
\hline From other family (1-4) & $1.33(0.41)$ & $1.32(0.42)$ & $1.32(0.42)$ & $1.32(0.43)$ & 0.2399 \\
\hline From friends $(1-4)$ & $1.27(0.34)$ & $1.25(0.32)$ & $1.26(0.32)$ & $1.26(0.34)$ & 0.1206 \\
\hline
\end{tabular}

Notes: SD: standard deviation; CESD: Center for Epidemiologic Studies Depression; $p$-values are based on the $t$-statistics of the group mean difference tests between the first (2006) and last (2012) waves.

Results of a series of linear mixed models (i.e., eight independent models) showed main and interaction effects of positive/negative social support on the association between MCC and depression (Table 2). Only positive spousal support (Model 1) significantly weakened the deleterious effect of MCC on depression $(p<0.001)$. By contrast, all negative social support from spouse (Model 2), children (Model 4), other family (Model 6), and friends (Model 8) significantly strengthened the deleterious effect of MCC on depression (all $p$-values $<0.001$ ). We depicted Figure 1 to further visualize the interaction effects of positive/negative social support on the associations between MCC and depression, suggesting a moderating effect. Although not all interactions were statistically significant, a clear trend was observed in Figure 1. That is, level of depression tends not to be influenced by the number of chronic conditions when receiving positive social support (except positive spousal support), and increased with increasing chronic conditions when receiving negative social support.
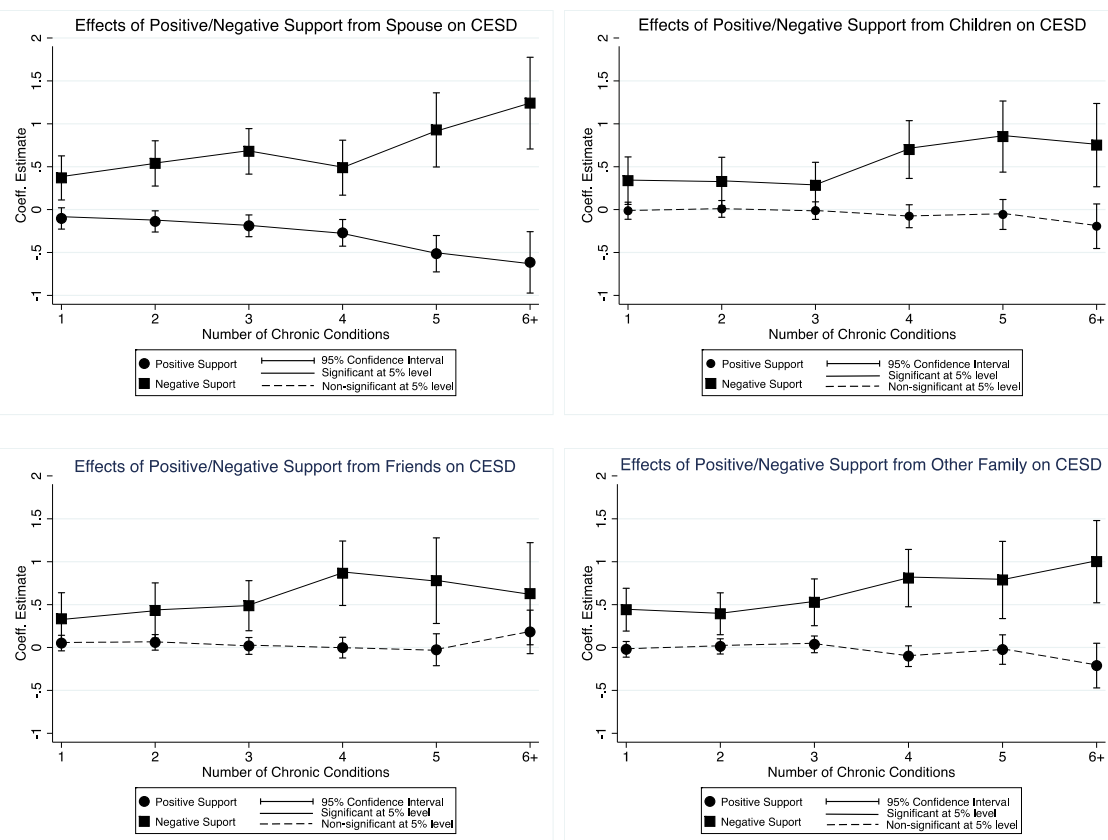

Figure 1. Effects of positive/negative supports from spouse, children, other family, and friends on CESD depression. 
Table 2. Adjusted moderating effect of social support on the association between Multiple Chronic Conditions (MCC) and CESD depression.

\begin{tabular}{|c|c|c|c|c|c|c|c|c|c|c|}
\hline & \multirow{2}{*}{ CESD Depression } & \multicolumn{4}{|c|}{ Positive Support } & \multicolumn{5}{|c|}{ Negative Support } \\
\hline & & Coef. & $p$-Value & & & & Coef. & $p$-Value & & \\
\hline \multirow[b]{2}{*}{ Model 1} & \multirow[b]{2}{*}{$\begin{array}{c}\text { MCC } \\
\text { Support from spouse } \\
\text { MCC } \times \text { Support from spouse } \\
\text { Intercept } \\
\text { R-squared }\end{array}$} & \multicolumn{4}{|c|}{ Spouse } & & \multicolumn{4}{|c|}{ Spouse } \\
\hline & & $\begin{array}{c}0.489 \\
-0.110 \\
-0.071 \\
0.912\end{array}$ & $\begin{array}{c}<0.001 \\
0.005 \\
<0.001 \\
0.001 \\
0\end{array}$ & $\begin{array}{c}0.387 \\
-0.186 \\
-0.103 \\
0.398 \\
13\end{array}$ & $\begin{array}{c}0.591 \\
-0.033 \\
-0.039 \\
1.426\end{array}$ & Model 2 & $\begin{array}{l}0.033 \\
0.115 \\
0.155 \\
0.142\end{array}$ & $\begin{array}{c}0.489 \\
0.152 \\
<0.001 \\
0.575 \\
0\end{array}$ & $\begin{array}{l}-0.060 \\
-0.042 \\
0.098 \\
-0.353 \\
4\end{array}$ & $\begin{array}{l}0.125 \\
0.273 \\
0.212 \\
0.636\end{array}$ \\
\hline Model 3 & $\begin{array}{c}\text { MCC } \\
\text { Support from children } \\
\text { MCC } \times \text { Support from children } \\
\text { Intercept } \\
\text { R-squared }\end{array}$ & $\begin{array}{c}0.367 \\
-0.148 \\
-0.017 \\
0.218\end{array}$ & $\begin{array}{r}\mathrm{Ch} \\
<0.001 \\
<0.001 \\
0.166 \\
0.284 \\
0\end{array}$ & $\begin{array}{l}\text { ren } \\
0.294 \\
-0.205 \\
-0.040 \\
-0.181 \\
06\end{array}$ & $\begin{array}{c}0.439 \\
-0.090 \\
0.007 \\
0.618\end{array}$ & Model 4 & $\begin{array}{c}0.112 \\
0.162 \\
0.141 \\
-0.324\end{array}$ & $\begin{array}{r}\text { Ch } \\
0.007 \\
0.042 \\
<0.001 \\
0.156 \\
0\end{array}$ & $\begin{array}{l}\text { ren } \\
0.031 \\
0.006 \\
0.086 \\
-0.772 \\
4\end{array}$ & $\begin{array}{l}0.193 \\
0.318 \\
0.196 \\
0.124\end{array}$ \\
\hline \multirow[b]{2}{*}{ Model 5} & \multirow[b]{2}{*}{$\begin{array}{c}\text { MCC } \\
\text { Support from other family } \\
\text { MCC } \times \text { Support from other } \\
\text { family } \\
\text { Intercept } \\
\text { R-squared }\end{array}$} & \multicolumn{4}{|c|}{ Other family } & & \multicolumn{4}{|c|}{ Other family } \\
\hline & & $\begin{array}{c}0.340 \\
-0.054 \\
-0.018 \\
0.330\end{array}$ & $\begin{array}{l}<0.001 \\
0.050 \\
0.118 \\
0.097 \\
0\end{array}$ & $\begin{array}{l}0.280 \\
-0.109 \\
-0.041 \\
-0.059 \\
96\end{array}$ & $\begin{array}{l}0.400 \\
0.000 \\
0.005 \\
0.719\end{array}$ & Model 6 & $\begin{array}{c}0.084 \\
0.091 \\
0.163 \\
-0.057\end{array}$ & $\begin{array}{r}0.034 \\
0.231 \\
<0.001 \\
0.797 \\
0\end{array}$ & $\begin{array}{l}0.006 \\
-0.058 \\
0.107 \\
-0.488 \\
1\end{array}$ & $\begin{array}{l}0.161 \\
0.240 \\
0.219 \\
0.375\end{array}$ \\
\hline Model 7 & $\begin{array}{c}\text { MCC } \\
\text { Support from friend } \\
\text { MCC } \times \text { Support from friend } \\
\text { Intercept } \\
\text { R-squared }\end{array}$ & $\begin{array}{c}0.298 \\
-0.047 \\
0.004 \\
0.231\end{array}$ & $\begin{array}{c}<0.001 \\
0.09 \\
0.713 \\
0.253 \\
0\end{array}$ & $\begin{array}{l}\text { dd } \\
0.241 \\
-0.101 \\
-0.019 \\
-0.165 \\
33\end{array}$ & $\begin{array}{l}0.354 \\
0.007 \\
0.027 \\
0.628\end{array}$ & Model 8 & $\begin{array}{c}0.111 \\
0.049 \\
0.151 \\
-0.091\end{array}$ & $\begin{array}{c}\mathrm{F} \\
0.01 \\
0.601 \\
<0.001 \\
0.682 \\
0\end{array}$ & $\begin{array}{l}\text { ld } \\
0.027 \\
-0.135 \\
0.087 \\
-0.530 \\
8\end{array}$ & $\begin{array}{l}0.196 \\
0.234 \\
0.216 \\
0.347\end{array}$ \\
\hline
\end{tabular}

Notes: All models (Model 1-8) were independently conducted to investigate the interaction effects between varying types of social support and MCC on CESD depression. We control for age, education, gender, race/ethnicity, and study year (wave) in all models. Standard errors are clustered at the person level. CESD: Center for Epidemiologic Studies Depression. MCC: multiple chronic conditions. 


\section{Discussion}

As a stress-buffering model suggests [54,55], we examined interaction effects of social support on late-life depression when study participants have multiple chronic conditions. To our best knowledge, it is the first effort to investigate the moderating effect of varying forms of social support as part of the social environment on the association between MCC and depression symptoms among older adults. While previous studies found significant effects of social support on mental health [56,57], the current study specifically suggested how varying social support plays different moderating roles in depressive symptomatology among older adults with MCC. Indeed, positive spousal support weakened the deleterious effect of MCC on depression while negative support from the spouse, children, other family, and friends strengthened this effect. These results suggest the importance of helping adults with MCC minimize potential negative social support while strengthening positive spousal support.

Most of all, the current study confirmed previous studies regarding the positive mental health effect of having positive spousal support for older adults with chronic conditions [58], weakening the negative effect of MCC on depressive symptomatology. A previous study similarly found that a high level of spousal support weakened the detrimental association between disease severity and depression while a low level strengthened this association [59]. It was also found that a husband's positive support significantly improved a wife's mental status especially when she had breast cancer [60]. In spite of this positive health aspect of having a spouse, there is an increasing trend of women living without a spouse from $35 \%$ in $1950,49 \%$ in 2000, to $51 \%$ in 2005 [61]. Living without a spouse (especially bereavement) has a negative mental health effect including grief and depression in late life [54]. In a meta-analysis, spousal care was only successful in reducing patients' depressive symptoms compared to forms of support from other family members [62]. The current study also found that this positive effect of social support was not shown with support from other family, children, or friends. This is presumably because the spouse often has the greatest potential to affect the patient's health due to the number of opportunities for support provision and intimate relationship [63]. Quality spousal care, filled with better understanding and affection, can help care recipients cope well with pain and symptoms related to chronic conditions [64], which in turn could improve depression [65]. Nevertheless, more studies should be done to better investigate the underlying mechanisms of the effects of positive spousal care on improving depression.

On the other hand, we also found there was a deleterious effect of negative spousal support on depression among older adults with MCC. A previous study found that spouses' negative (pressuring) support worsened the health status of older adults with osteoarthritis [64]. Depressive symptomatology of older adults who had MCC can be especially worsened when they reported having negative spousal support [66]. Another study showed that negative interaction with a husband increased depressive symptomatology and decreased self-care behaviors when a wife suffered from osteoarthritis [67]. Even spousal disability increased levels of emotional loneliness [68]. These studies encourage us pay more attention to the quality of spousal care and marriage in later life to help improve patients' mental health [58]. It is easy to speculate that care provision for a spouse with MCC could generate a high level of caregiver burden or fatigue that can be a result of an imbalance between caregiving demands and caregiving resources and, therefore, lead to negative health outcomes among caregivers [69,70]. Compared to non-caregiving control groups, older adult spousal caregivers experienced more cognitive functioning difficulties, stress, loneliness, depression, anxiety, and poorer mental health [71]. On the other hand, spouses with greater network support experienced fewer depressive symptoms when the patient's illness was more severe [59]. Preparing resources and maintaining strong social support systems could improve the health status of older family caregivers, which helps to ease caregiver fatigue and results in better care for their spouses [72].

Interestingly, the current study found that negative social support from other family members, adult children, and friends strengthened the deleterious effect of MCC on depression among older adults. It is often cited that older adults tend to feel emotional and lonely when they have smaller social networks and less contact with children [58]. However, the current study was not able to detect 
any positive effect of social support from other family, children, and friends. Instead, the current study indicated that troubled family or friends' relationships could have a harmful effect on mental health among older adults with MCC. As a reminder, HRS asked older adults experiencing negative social support about the extent of them: (1) making too many demands on you; (2) criticizing you; (3) letting you down when you are counting on them; and (4) getting on your nerves. Although it is beyond the scope of this study, the negative health effects of support from friends or family members found in this study point to potential elder abuse, neglect, or exploitation that may be prevalent (but under-reported) and committed by older adults' friends or family members [73]. A meta-analysis suggested that risk factors of elder abuse include the perpetrator (caregiver burden or stress, psychiatric illness or psychological problems), relationship (family disharmony, poor or conflictual relationships), and environment (low social support, living with others) [73]. While referring to a high prevalence of elder abuse ( $10 \%$ in the U.S.) in community-dwelling older adults [74], older adults with MCC can be susceptible targets for perpetrators because they are prone to being disabled and having cognitive impairment $[75,76]$. Nevertheless, the study findings do not negate the importance of social support from others; instead, the current study warns of potential negative mental health impacts of bad or low quality relationships, especially when older adults carry the heavy burden of chronic conditions. Closely working with Adult Protective Services [77], primary care physicians should be more attentive to any irregular symptoms of elder abuse or negligence when the depression of elderly patients with MCC worsens.

Several limitations of the current study should be noted. First, the current study is based on an observational study, which did not allow for causal examination. Second, in spite of having valid psychometrics, all measures are self-reported (including MCC, CES-D depression, social supports), introducing potential reporting bias relative to more clinically based data [78]. Third and last, this study was limited in its measure of in-depth negative and positive social support mechanisms including underlying reasons (especially for potential elder abuse or negligence as part of negative social supports). Future studies need to construct more valid models to attain a better understanding of the dynamics of MCC, depression, and social support among older adults.

\section{Conclusions}

We believe this study makes an important contribution to the gerontological literature by showing the moderating effects of varying forms of social support on the association between MCC and depression among older adults. The current study confirmed the importance of quality spousal support and care as part of a positive social environment to maintain the mental health of older adults when they have MCC. At the same time, our findings suggest that identifying and minimizing the deleterious health effect of negative social supports could help older adults improve their depression, which could in turn help them manage their chronic conditions and experience positive aging. At the community-level, concerted efforts are needed to first identify at-risk older adults with MCC, assure their social connectedness with family members and local communities, and closely monitor their mental health status related to MCC.

Acknowledgments: We thank student reviewers for their help in the manuscript review process: Asos Mahmood, Kendall Morton, Anand Saha, Oluwaseyi Isehunwa, Richa Kabra, Hyunmin Kim, and Jennifer Sykes.

Author Contributions: SangNam Ahn conceived the research questions, analyzed the data, and wrote the manuscript; Seonghoon Kim cleaned the data, analyzed the data, and provided critical review; and Hongmei Zhang conceived the research questions and provided critical review.

Conflicts of Interest: The authors declare no conflict of interest.

\section{References}

1. Chapman, D.P.; Perry, G.S. Depression as a major component of public health for older adults. Prev. Chronic Dis. 2008, 5, 1-9.

2. CDC. Depression Is Not a Normal Part of Growing Older; CDC: Atlanta, GA, USA, 2015. 
3. Heo, M.; Murphy, C.F.; Fontaine, K.R.; Bruce, M.L.; Alexopoulos, G.S. Population projection of U.S. adults with lifetime experience of depressive disorder by age and sex from year 2005 to 2050. Int. J. Geriatr. Psychiatry 2008, 23, 1266-1270. [CrossRef] [PubMed]

4. Blazer, D.G. Depression in late life: Review and commentary. Biol. Sci. Med. Sci. 2003, 58, M249-M265. [CrossRef]

5. Lockwood, K.A.; Alexopoulos, G.S.; van Gorp, W.G. Executive dysfunction in geriatric depression. Am. J. Psychiatry 2002, 159, 1119-1126. [CrossRef] [PubMed]

6. Fiske, A.; Wetherell, J.L.; Gatz, M. Depression in older adults. Ann. Rev. Clin. Psychol. 2009, 5, 363-389. [CrossRef] [PubMed]

7. Brett, C.E.; Gow, A.J.; Corley, J.; Pattie, A.; Starr, J.M.; Deary, I.J. Psychosocial factors and health as determinants of quality of life in community-dwelling older adults. Qual. Life Res. 2012, 21, 505-516. [CrossRef] [PubMed]

8. U.S. Census Bureau. The Next Four Decades-The Older Population in the United States: 2010 to 2050; U.S. Census Bureau: Washington, DC, USA, 2010.

9. Reynolds, C.F., III; Cuijpers, P.; Patel, V.; Cohen, A.; Dias, A.; Chowdhary, N.; Okereke, O.I.; Dew, M.A.; Anderson, S.J.; Mazumdar, S. Early intervention to reduce the global health and economic burden of major depression in older adults. Ann. Rev. Public Health 2012, 33, 123-135. [CrossRef] [PubMed]

10. Donohue, J.M.; Pincus, H.A. Reducing the societal burden of depression. Pharmacoeconomics 2007, 25, 7-24. [CrossRef] [PubMed]

11. Egede, L.E. Major depression in individuals with chronic medical disorders: Prevalence, correlates and association with health resource utilization, lost productivity and functional disability. Gen. Hosp. Psychiatry 2007, 29, 409-416. [CrossRef] [PubMed]

12. Emptage, N.P.; Sturm, R.; Robinson, R.L. Depression and comorbid pain as predictors of disability, employment, insurance status, and health care costs. Psychiatry Serv. 2005, 56, 468-474. [CrossRef] [PubMed]

13. Unützer, J. Late-life depression. N. Engl. J. Med. 2007, 357, 2269-2276. [CrossRef] [PubMed]

14. DiNapoli, E.A.; Scogin, F.R. Late-Life Depression; Oxford University Press: London, UK, 2014; p. 412.

15. Felger, J.C.; Haroon, E.; Miller, A.H. Risk and resilience: Animal models shed light on the pivotal role of inflammation in individual differences in stress-induced depression. Biol. Psychiatry 2015, 78, 7-9. [CrossRef] [PubMed]

16. Köhler, O.; Petersen, L.; Mors, O.; Gasse, C. Inflammation and depression: Combined use of selective serotonin reuptake inhibitors and nsaids or paracetamol and psychiatric outcomes. Brain Behav. 2015, 5. [CrossRef] [PubMed]

17. Marmorstein, N.R.; Iacono, W.G.; Legrand, L. Obesity and depression in adolescence and beyond: Reciprocal risks. Int. J. Obes. 2014, 38, 906-911. [CrossRef] [PubMed]

18. Strine, T.W.; Mokdad, A.H.; Dube, S.R.; Balluz, L.S.; Gonzalez, O.; Berry, J.T.; Manderscheid, R.; Kroenke, K. The association of depression and anxiety with obesity and unhealthy behaviors among community-dwelling U.S. adults. Gen. Hosp. Psychiatry 2008, 30, 127-137. [CrossRef] [PubMed]

19. Gold, D.T.; Solimeo, S. Osteoporosis and depression: A historical perspective. Curr. Osteoporos. Rep. 2006, 4 , 134-139. [CrossRef]

20. Wu, Q.; Magnus, J.H.; Liu, J.; Bencaz, A.F.; Hentz, J.G. Depression and low bone mineral density: A meta-analysis of epidemiologic studies. Osteoporos. Int. 2009, 20, 1309-1320. [CrossRef] [PubMed]

21. Kuzava, S.; Doyle, C.; Gustafsson, H.; Werner, E.; Monk, C. Inflammation and depression in pregnant adolescents with asthma. Brain Behav. Immun. 2014, 40, e48-e49. [CrossRef]

22. Mancuso, C.A.; Westermann, H.; Choi, T.N.; Wenderoth, S.; Briggs, W.M.; Charlson, M.E. Psychological and somatic symptoms in screening for depression in asthma patients. J. Asthma 2008, 45, 221-225. [CrossRef] [PubMed]

23. Sale, J.E.M.; Gignac, M.; Hawker, G. The relationship between disease symptoms, life events, coping and treatment, and depression among older adults with osteoarthritis. J. Rheumatol. 2008, 35, 335-342. [PubMed]

24. Golden, S.H.; Lazo, M.; Carnethon, M.; Bertoni, A.G.; Schreiner, P.J.; Roux, A.V.D.; Lee, H.B.; Lyketsos, C. Examining a bidirectional association between depressive symptoms and diabetes. JAMA 2008, 299, 2751-2759. [CrossRef] [PubMed] 
25. Maraldi, C.; Volpato, S.; Penninx, B.W.; Yaffe, K.; Simonsick, E.M.; Strotmeyer, E.S.; Cesari, M.; Kritchevsky, S.B.; Perry, S.; Ayonayon, H.N. Diabetes mellitus, glycemic control, and incident depressive symptoms among 70- to 79-year-old persons: The health, aging, and body composition study. Arch. Int. Med. 2007, 167, 1137-1144. [CrossRef] [PubMed]

26. Li, C.; Ford, E.S.; Strine, T.W.; Mokdad, A.H. Prevalence of depression among U.S. adults with diabetes findings from the 2006 behavioral risk factor surveillance system. Diabetes Care 2008, 31, 105-107. [CrossRef] [PubMed]

27. Krishnan, K.R.R.; Tupler, L.A.; Ritchie, J.C.; McDonald, W.M.; Knight, D.L.; Nemeroff, C.B.; Carroll, B.J. Apolipoprotein E- $\varepsilon 4$ frequency in geriatric depression. Biol. Psychiatry 1996, 40, 69-71. [CrossRef]

28. Pan, A.; Sun, Q.; Okereke, O.I.; Rexrode, K.M.; Hu, F.B. Depression and risk of stroke morbidity and mortality: A meta-analysis and systematic review. JAMA 2011, 306, 1241-1249. [CrossRef] [PubMed]

29. Fann, J.R.; Fan, M.-Y.; Unützer, J. Improving primary care for older adults with cancer and depression. J. Gen. Int. Med. 2009, 24, 417-424. [CrossRef] [PubMed]

30. Bosworth, H.B.; Bartash, R.M.; Olsen, M.K.; Steffens, D.C. The association of psychosocial factors and depression with hypertension among older adults. Int. J. Geriatr. Psychiatry 2003, 18, 1142-1148. [CrossRef] [PubMed]

31. Bogner, H.R.; de Vries, H.F. Integration of depression and hypertension treatment: A pilot, randomized controlled trial. Ann. Fam. Med. 2008, 6, 295-301. [CrossRef] [PubMed]

32. Yen, I.H.; Syme, S.L. The social environment and health: A discussion of the epidemiologic literature. Ann. Rev. Public Health 1999, 20, 287-308. [CrossRef] [PubMed]

33. Ouellete Kobasa, S.C.; Spinetta, J.J.; Cohen, J.; Crano, W.D.; Hatchett, S.; Kaplan, B.H.; Lansky, S.B.; Prout, M.N.; Ruckdeschel, J.C.; Siegel, K. Social environment and social support. Cancer 1991, 67, 788-793. [CrossRef]

34. Holtfreter, K.; Reisig, M.D.; Turanovic, J.J. Self-rated poor health and loneliness in late adulthood: Testing the moderating role of familial ties. Adv. Life Course Res. 2015, 27, 61-68. [CrossRef]

35. Cornwell, E.Y.; Waite, L.J. Social disconnectedness, perceived isolation, and health among older adults. Health Soc. Behav. 2009, 50, 31-48. [CrossRef]

36. Krause, N. Social support, stress, and well-being among older adults. J. Gerontol. 1986, 41, 512-519. [CrossRef] [PubMed]

37. Penninx, B.W.J.H.; Van Tilburg, T.; Deeg, D.J.H.; Kriegsman, D.M.W.; Boeke, A.J.P.; Van Eijk, J.T.M. Direct and buffer effects of social support and personal coping resources in individuals with arthritis. Soc. Sci. Med. 1997, 44, 393-402. [CrossRef]

38. Nolen-Hoeksema, S.; Ahrens, C. Age differences and similarities in the correlates of depressive symptoms. Psychol. Aging 2002, 17, 116-124. [CrossRef] [PubMed]

39. George, L.K.; Blazer, D.G.; Hughes, D.C.; Fowler, N. Social support and the outcome of major depression. Br. J. Psychiatry 1989, 154, 478-485. [CrossRef]

40. Kristof, L.; Fortinsky, R.H.; Kellett, K.; Porter, M.; Robison, J. Experiences of informal caregivers of older adults transitioned from nursing homes to the community through the money follows the person demonstration. J. Aging Soc. Policy 2016. [CrossRef] [PubMed]

41. Adelman, R.D.; Tmanova, L.L.; Delgado, D.; Dion, S.; Lachs, M.S. Caregiver burden: A clinical review. JAMA 2014, 311, 1052-1060. [CrossRef] [PubMed]

42. Wallace, R.B.; Herzog, A.R. Overview of the health measures in the health and retirement study. J. Hum. Resour. 1995, 30, S84-S107. [CrossRef]

43. Chopik, W.J.; Kim, E.S.; Smith, J. Changes in optimism are associated with changes in health over time among older adults. Soc. Psychol. Personal. Sci. 2015, 6, 814-822. [CrossRef] [PubMed]

44. Heeringa, S.G.; Connor, J. Technical Description of the Health and Retirement Study Sample Design; HRS/AHEAD Documentation Report DR-002; Institute for Social Research, University of Michigan: Ann Aebor, MI, USA, 1995.

45. National Institute on Aging. Growing Oldear in America: The Health and Retirement Study; National Institute on Aging: Bethesda, MD, USA, 2007.

46. Townsend, A.L.; Miller, B.; Guo, S. Depressive symptomatology in middle-aged and older married couples a dyadic analysis. Psychol. Sci. Soc. Sci. 2001, 56, S352-S364. [CrossRef] 
47. Radloff, L.S. The CES-D scale a self-report depression scale for research in the general population. Appl. Psychol. Meas. 1977, 1, 385-401. [CrossRef]

48. Hann, D.; Winter, K.; Jacobsen, P. Measurement of depressive symptoms in cancer patients: Evaluation of the center for epidemiological studies depression scale (CES-D). J. Psychosom. Res. 1999, 46, 437-443. [CrossRef]

49. Yang, F.M.; Cazorla-Lancaster, Y.; Jones, R.N. Within-group differences in depression among older hispanics living in the United States. Psychol. Sci. Soc. Sci. 2008, 63, P27-P32. [CrossRef]

50. Lewinsohn, P.M.; Seeley, J.R.; Roberts, R.E.; Allen, N.B. Center for epidemiologic studies depression scale (CES-D) as a screening instrument for depression among community-residing older adults. Psychol. Aging 1997, 12, 277-287. [CrossRef] [PubMed]

51. Zivin, K.; Llewellyn, D.J.; Lang, I.A.; Vijan, S.; Kabeto, M.U.; Miller, E.M.; Langa, K.M. Depression among older adults in the United States and England. Am. J. Geriatr. Psychiatry 2010, 18, 1036-1044. [CrossRef] [PubMed]

52. Morrow-Howell, N.; Putnam, M.; Lee, Y.S.; Greenfield, J.C.; Inoue, M.; Chen, H. An investigation of activity profiles of older adults. Psychol. Sci. Soc. Sci. 2014. [CrossRef] [PubMed]

53. Clarke, P.; Fisher, G.; House, J.; Smith, J.; Weir, D. Guide to Content of the HRS Psychosocial Leave-Behind Participant Lifestyle Questionnaires: 2004 and 2006; University of Michigan Survey Research Center: Ann Arbor, MI, USA, 2008.

54. House, J.S.; Landis, K.R.; Umberson, D. Social relationships and health. Science 1988, 241, 540-545. [CrossRef] [PubMed]

55. Cohen, S. Social relationships and health. Am. Psychol. 2004, 59, 676-684. [CrossRef] [PubMed]

56. Brock, R.L.; Lawrence, E. A longitudinal investigation of stress spillover in marriage: Does spousal support adequacy buffer the effects? J. Fam. Psychol. 2008, 22, 11-20. [CrossRef] [PubMed]

57. Umberson, D.; Montez, J.K. Social relationships and health a flashpoint for health policy. J. Health Soc. Behav. 2010, 51, S54-S66. [CrossRef] [PubMed]

58. De Jong Gierveld, J.; van Groenou, M.B.; Hoogendoorn, A.W.; Smit, J.H. Quality of marriages in later life and emotional and social loneliness. Psychol. Sci. Soc. Sci. 2009. [CrossRef] [PubMed]

59. Revenson, T.A.; Deborah Majerovitz, S. The effects of chronic illness on the spouse. Social resources as stress buffers. Arthritis Rheum. 1991, 4, 63-72. [CrossRef]

60. Maly, R.C.; Umezawa, Y.; Leake, B.; Silliman, R.A. Mental health outcomes in older women with breast cancer: Impact of perceived family support and adjustment. Psycho-Oncology 2005, 14, 535-545. [CrossRef] [PubMed]

61. Roberts, S. 51\% of women are now living without spouse. The New York Times, 16 January 2007.

62. Martire, L.M.; Lustig, A.P.; Schulz, R.; Miller, G.E.; Helgeson, V.S. Is it beneficial to involve a family member? A meta-analysis of psychosocial interventions for chronic illness. Health Psychol. 2004, 23, 599-611. [CrossRef] [PubMed]

63. Kiecolt-Glaser, J.K.; Newton, T.L. Marriage and health: His and hers. Psychol. Bull. 2001, 127, 472-503. [CrossRef] [PubMed]

64. Fekete, E.M.; Stephens, M.A.P.; Druley, J.A.; Greene, K.A. Effects of spousal control and support on older adults' recovery from knee surgery. J. Fam. Psychol. 2006, 20, 302-310. [CrossRef] [PubMed]

65. Dean, A.; Kolody, B.; Wood, P. Effects of social support from various sources on depression in elderly persons. J. Health Soc. Behav. 1990, 31, 148-161. [CrossRef] [PubMed]

66. Druley, J.A.; Townsend, A.L. Self-esteem as a mediator between spousal support and depressive symptoms: A comparison of healthy individuals and individuals coping with arthritis. Health Psychol. 1998, 17, $255-261$. [CrossRef] [PubMed]

67. Matire, L.M.; Stephens, M.A.P.; Druley, J.A.; Wojno, W.C. Negative reactions to received spousal care: Predictors and consequences of miscarried support. Health Psychol. 2002, 21, 167-176. [CrossRef]

68. Korporaal, M.; van Groenou, M.I.B.; van Tilburg, T.G. Effects of own and spousal disability on loneliness among older adults. J. Aging Health 2008, 20, 306-325. [CrossRef] [PubMed]

69. Teel, C.S.; Press, A.N.; Lindgren, C.L.; Nichols, E.G. Fatigue among elders in caregiving and noncaregiving roles. Western J. Nurs. Res. 1999, 21, 498-520. [CrossRef]

70. Dura, J.R.; Haywood-Niler, E.; Kiecolt-Glaser, J.K. Spousal caregivers of persons with alzheimer's and parkinson's disease dementia: A preliminary comparison. Gerontologist 1990, 30, 332-336. [CrossRef] [PubMed] 
71. Lavela, S.L.; Ather, N. Psychological health in older adult spousal caregivers of older adults. Chronic Ill. 2010, 6, 67-80. [CrossRef] [PubMed]

72. Ahn, S.; Hochhalter, A.K.; Moudouni, D.K.M.; Smith, M.L.; Ory, M.G. Self-reported physical and mental health of older adults: The roles of caregiving and resources. Maturitas 2012, 71, 62-69. [CrossRef] [PubMed]

73. Johannesen, M.; LoGiudice, D. Elder abuse: A systematic review of risk factors in community-dwelling elders. Age Ageing 2013. [CrossRef] [PubMed]

74. CDC. Elder Abuse Prevention; CDC: Atlanta, GA, USA, 2015.

75. Dong, X.; Simon, M. Association between elder abuse and metabolic syndromes: Findings from the Chicago Health and Aging Project. Gerontology 2015, 61, 389-398. [CrossRef] [PubMed]

76. Luu, A.D.; Liang, B.A. Clinical case management; a strategy to coordinate detection, reporting, and prosecution of elder abuse. Cornell J. Law Public Policy 2005, 15, 165-196.

77. Lachs, M.S.; Williams, C.S.; O’Brien, S.; Pillemer, K.A. Adult protective service use and nursing home placement. Gerontologist 2002, 42, 734-739. [CrossRef] [PubMed]

78. Ezzati, M.; Martin, H.; Skjold, S.; Vander Hoorn, S.; Murray, C.J.L. Trends in national and state-level obesity in the USA after correction for self-report bias: Analysis of health surveys. J. R. Soc. Med. 2006, 99, 250-257. [CrossRef] [PubMed]

(C) 2016 by the authors; licensee MDPI, Basel, Switzerland. This article is an open access article distributed under the terms and conditions of the Creative Commons Attribution (CC-BY) license (http://creativecommons.org/licenses/by/4.0/). 